\title{
REPARTYCJA NA POLU REPROGRAFII - DOŚWIADCZENIA STOWARZYSZENIA KOPIPOL
}

Na początku lat dziewięćdziesiątych rozpoczął się dynamiczny rozwój reprograficznej techniki kopiowania jako prostego i taniego sposobu wykonywania kopii. Szybko spadające ceny ich wykonania tą techniką zadecydowały o lawinowo rosnącej skali korzystania w taki sposób z efektów cudzej twórczości w ramach dozwolonego użytku osobistego. Szczególnie odnotowane zostało to w obszarze nauki, w którym artykuły naukowe i monografie, jak również podręczniki i skrypty - wcześniej w zasadzie niekopiowane - stały się przedmiotem masowej eksploatacji.

Moca uchwalonej w $1994 \mathrm{r}$. ustawy o prawie autorskim i prawach pokrewnych ${ }^{1}$ ustawodawca wprowadził do polskiego porządku prawnego opłaty mające rekompensować straty ponoszone przez twórców na skutek eksploatowania przedmiotów ich praw autorskich za pomoca techniki reprograficznej.

I tak w 1995 r. powstało Stowarzyszenie Zbiorowego Zarządzania Prawami Autorskimi Twórców Dzieł Naukowych i Technicznych, które nieco później zaczęto nazywać KOPIPOL-em. Statutowym zadaniem KOPIPOL-u jest zbiorowe zarządzanie autorskimi prawami majątkowymi twórców dzieł naukowych i technicznych. Na podstawie art. 104 pr.aut. KOPIPOL wystapił o zezwolenie na zbiorowe zarządzanie prawami autorskimi, obejmujące w szczególności inkaso i podział na podstawie art. 201, 30 ust. 2 pr.aut. Właściwy do wydawania takich zezwoleń Minister Kultury i Dziedzictwa Narodowego udzielił KOPIPOL-owi zezwolenia na zbiorowe zarządzanie ${ }^{2}$.

Rozporządzeniem z 2 czerwca 2003 r. KOPIPOL wskazany został ponadto jako właściwa organizacja zbiorowego zarządzania (OZZ) uprawniona do pobierania i podziału na rzecz twórców opłat od urządzeń reprograficznych oraz związanych z nimi czystych nośników ${ }^{3}$.

Rozporządzeniem Ministra Kultury z 27 czerwca 2003 r. ${ }^{4}$ KOPIPOL na podstawie art. $20^{1}$ pr.aut. umocowany został, jako tzw. wskazana OZZ, do inkasa (i jego podziału) od handlowego kopiowania egzemplarzy utworów na

1 Ustawa z 4 lutego 1994 r. o prawie autorskim i prawach pokrewnych, t.jedn.: Dz. U. 2006, Nr 90, poz. 631 ze zm. (dalej jako: pr.aut.).

${ }^{2}$ Obecnie obowiązuje w tym zakresie decyzja z 19 listopada 2003 r., MP 2009, nr 21, poz. 270.

${ }^{3}$ Por. $\$ 4$ pkt 1 rozporządzenia Ministra Kultury z 2 czerwca 2003 r. w sprawie określenia kategorii urządzeń i nośników służących do utrwalania utworów oraz opłat od tych urządzeń i nośników z tytułu ich sprzedaży przez producentów i importerów, Dz. U. 2003, Nr 105, poz. 991.

${ }_{4}$ Dz. U. Nr 132, poz. 1232. 
zamówienie osób wykorzystujących je na własny użytek osobisty. W rozporządzeniu tym wynagrodzenia określono jako „opłaty”. Jest to kwestia kontrowersyjna - w doktrynie prawa autorskiego analizuje ja Dorota Sokołowska w monografii Prawo twórcy do wynagrodzenia $w$ prawie autorskim ${ }^{5}$.

Problematyka opłat ma fundamentalne znaczenie zarówno teoretyczne, jak i praktyczne. W jej obrębie kwestią zasadniczą jest ujęcie koncepcji opłat w relacji do charakteru prawnego i ujęcia w obowiązującej ustawie wynagrodzenia autorskiego jako komponentu treści majątkowych praw twórcy do utworu. Zagadnienia te są ostatnio żywo dyskutowane i wzbudziły liczne kontrowersje, zarówno w kwestiach podstawowych, jak i szczegółowych. Istotnym wydarzeniem sprzyjającym rozwiązaniu tych rozbieżności i sporów jest ukazanie się fundamentalnej w polskim prawie autorskim monografii Sokołowskiej, wszechstronnie i w sposób krytyczny poddającej analizie (również w relacji do problematyki opłat) prawa twórcy do wynagrodzenia ${ }^{6}$.

Kwestie związane $\mathrm{z}$ charakterem opłat w sposób szczegółowy zostały podjęte w polskiej literaturze zarówno przez Sokołowską (w jej ostatnio wydanej kolejnej monografii`), a także przez innych autorów. Były mianowicie przedmiotem ogólnopolskiej konferencji naukowej z udziałem przedstawicieli kilku ośrodków naukowych w Polsce oraz praktyki poświęconej opłatom w szerokim ujęciu teoretycznym i praktycznym. Rezultatem przeprowadzonych debat sa materiały wydane $\mathrm{w}$ tomie pokonferencyjnym ${ }^{8}$. W tym kontekście wydaje się zbędne powtarzanie w niniejszym opracowaniu głównych tez dotyczący opłat, wobec ich wszechstronnego zaprezentowania na tej konferencji, zwłaszcza w wystapieniach wprowadzających do dyskusji, autorstwa Joanny Błeszyńskiej-Wysockiej i Doroty Sokołowskiej.

W konsekwencji dalsze rozważania zostana skoncentrowane na kwestiach praktycznych, związanych z inkasem i podziałem opłat reprograficznych przeznaczonych dla twórców, pobieranych na podstawie art. 20 pr.aut. Jest to bowiem podstawowy fragment działalności KOPIPOL-u. Jednocześnie nasza znaczna aktywność w tym zakresie, zwłaszcza na polu dochodzenia opłat na drodze sądowej, jest największa, mierząc ją zarówno liczbą prowadzonych postępowań przed sądami, jak i fundamentalnym znaczeniem zapadłych w tych sprawach wyroków o charakterze precedensowym, mających zasadnicze znaczenie w odniesieniu do całości problematyki prawnej opłat należnych na podstawie art. 20 pr.aut.

\footnotetext{
5 WN UAM, Poznań 2013, ss. 344.

6 Ibidem.

7 Opłaty reprograficzne, Lex a Wolters Kluwer business, Warszawa 2014, passim.

8 J. Błeszyńska-Wysocka (red.), Kompensata strat twórców, artystów wykonawców i producentów egzemplarzy utworów kopiowanych w ramach własnego użytku osobistego za pomocq urzqdzeń cyfrowych, Stowarzyszenie Absolwentów Wydziału Prawa i Administracji Uniwersytetu Warszawskiego 2014. Tom ten zawiera szereg opracowań problematyki tej kompensaty, zarówno w aspektach teoretycznych, w tym D. Sokołowskiej (Charakter prawny opłat pobieranych na podstawie art. 20 ustawy o prawie autorskim i prawach pokrewnych, s. 49 i n.) oraz J. Błeszyńskiej-Wysockiej (Koncepcja opłat od importerów i producentów urzadzeń, kompensujacych kopiowanie egzemplarzy utworów w ramach własnego użytku osobistego w świetle art. 20 PrAut, ibidem, s. 9 i n.), jak również doświadczeń praktycznych, w szczególności OZZ dokonujących poboru i podziału opłat.
} 
Jak wskazano, inkaso realizowane jest w dwóch obszarach, z których pierwszy, na podstawie art. 20 pr.aut., stanowią opłaty od importerów i producentów (teoretycznie) urządzeń reprograficznych i związanych z nimi czystych nośników. Opłata ta, zwana z angielska machine levy, stanowi około 98\% wpływów KOPIPOL-u. Drugi obszar to opłaty od, mówiąc popularnie, punktów ksero, o czym stanowi art. $20^{1}$ pr.aut., oraz wynagrodzenia z tytułu reprodukowania w granicach art. 30 ust. 1 pr.aut.

Pozornie proste inkaso opłat reprograficznych okazało się w praktyce naszej działalności procesem skomplikowanym, kosztownym i czasochłonnym. Przyczyną takiego stanu rzeczy są nagminne próby unikania opłat, co zmusza KOPIPOL do egzekwowania ich na drodze postępowań sądowych.

Prawdziwym wyzwaniem, jakie stanęło przed KOPIPOL-em, było opracowanie i wdrożenie systemu ich podziału. Początkowo podstawowym ograniczeniem możliwości realizacji jakiejkolwiek repartycji w środowisku naukowym był niski poziom inkasa, utrzymujący się w pierwszych dziewięciu latach na poziomie kilkuset tysięcy złotych rocznie. Skutkiem takiego stanu była nieracjonalność wdrażania repartycji indywidualnej, jak również niekorzystna relacja pomiędzy kosztami naszej działalności i kwotami efektywnie przeznaczonymi dla twórców. Jest to problem każdej nowej OZZ, jako że nie korzysta ona z żadnych zewnętrznych (poza inkasem opłat) źródeł finansowania swojej działalności. Zadecydowało to o wdrożeniu w owym czasie systemu tzw. repartycji pośredniej, zwanej też funduszową.

Drugim problemem było wnoszenie zaniżonych opłat przez producentów i importerów sprzętu, będące wynikiem sprzecznego z delegacją zawartą w art. 20 ust. 5 pr.aut. treścią rozporządzenia ministra określającego przedmiotowy zakres urządzeń objętych opłatami, jak i rażąco zaniżających wysokość opłat - sprzeczne z dyrektywą tej delegacji, a przede wszystkim z art. 20 ust. 1 pr.aut. Częściowa, jednakże zdecydowanie niewystarczająca do uznania zgodności rozporządzenia z ustawa, była zmiana przepisów ${ }^{9}$, obejmująca urealnienie wysokości opłat pobieranych od producentów papieru kserograficznego oraz objęcie opłatą nowych urządzeń umożliwiających kopiowanie utworów spowodowały, że inkasowane przez KOPIPOL opłaty zaczęły stanowić realna wartość jako środki mające stanowić rekompensatę za możliwość kopiowania utworów w ramach dozwolonego użytku ${ }^{10}$.

Pierwszym etapem podziału opłat jest ustalenie wszystkich kategorii twórczości kopiowanej reprograficznie oraz wysokości przypadających na nie udziałów. Jak wykazują badania statystyczne ${ }^{11}$, oprócz twórczości naukowej, kopiowane reprograficznie są także innego rodzaju utwory słowne (w tym literackie) i słowno-muzyczne (w tym ludowe), a także - w śladowych ilościach utwory: architektoniczne, plastyczne i fotograficzne. KOPIPOL dokonuje re-

\footnotetext{
${ }^{9}$ Wprowadzona rozporządzeniem Ministra Kultury i Dziedzictwa Narodowego z 12 maja 2011 r., Dz. U. Nr 105, poz. 616.

${ }^{10}$ Rozporządzenie Ministra Kultury i Dziedzictwa Narodowego z 12 maja 2011 r. zmieniające rozporządzenie w sprawie określenia kategorii urządzeń i nośników służących do utrwalania utworów oraz opłat od tych urządzeń i nośników z tytułu ich sprzedaży przez producentów i importerów, Dz. U. 2011, Nr. 105, poz. 616.

11 J. Błeszyńska-Wysocka (red.), op. cit., s. 95-104.
} 
partycji indywidualnej pomiędzy twórców dzieł naukowych i technicznych, dla których jest on organizacją właściwa. Dla pozostałych kategorii twórczości organizacjami właściwymi sa: ZAiKS, STL ZPAP, ZPAF i SARP.

KOPIPOL jest pierwszą w Polsce organizacja, która na bieżąco, w odstępach kwartalnych, przekazuje opłaty organizacjom zbiorowego zarządzania reprezentujacym uprawnione kategorie twórczości. Oznacza to, że KOPIPOL jako jedyna organizacja w kraju dokonuje rozliczeń opłaty zgodnie z obowiązującymi w tym zakresie przepisami prawa.

W związku z sukcesywnym wzrostem inkasa, będącym efektem szeroko zakrojonej przez KOPIPOL akcji sądowego dochodzenia opłat reprograficznych, możliwe było przejście z pierwotnego, funduszowego systemu repartycji na system repartycji bezpośredniej, zwanej również indywidualna. Prace nad systemem rozpoczęły się w 2007 r., a już w drugiej połowie 2010 r. pierwsi twórcy otrzymali należne im wynagrodzenia. Do chwili obecnej repartycją indywidualną objęliśmy wszystkie środki zainkasowane w latach 2007-2013 oraz te, których nie udało nam się wypłacić przed 2007 r. w ramach wspomnianego już systemu repartycji funduszowej.

To było trudne zadanie. Po pierwsze, same opłaty były nową konstrukcja w polskim porządku prawnym. Po drugie, nie było żadnych krajowych wzorców czy wypracowanych rozwiązań, które mogłyby być wskazówka, jak ukształtować system podziału opłat.

Konieczne było sięgnięcie do wzorców europejskich, głównie skandynawskich. KOPIPOL zapożyczył z nich zasadę, wedle której podstawą podziału sa wyłącznie wyniki badań statystycznych struktury kopiowania reprograficznego. To w ich ramach ustalane są rodzaje twórczości kopiowanej reprograficznie oraz przypadające na nie udziały. Stąd wynika podział pieniędzy pomiędzy uprawnione organizacje zbiorowego zarządzania.

Rokrocznie powtarzane pomiary statystyczne wykonuje dla KOPIPOL-u wybrany na podstawie konkursu ofert CEM Instytut Badań Rynku i Opinii Publicznej z Krakowa, kierowany wówczas przez prof. Jana Jerschinę z Uniwersytetu Jagiellońskiego. Pracownia prof. Jerschiny zastosowała w badaniach „metodę podwójnej kopii”, polegającą na wykonaniu w czasie badania i na jego potrzeby drugiego egzemplarza wszystkiego, co w tym czasie było kopiowane reprograficznie w obserwowanym punkcie ksero. Rozwiąanie to przekształca badania statystyczne w pomiar, czyniąc jego wyniki bardzo precyzyjnymi i co najważniejsze - obiektywnymi.

$\mathrm{Na}$ podstawie tak zrealizowanych pomiarów statystycznych uzyskuje się udziały poszczególnych kategorii twórczości i kwoty należne innym OZZ niż KOPIPOL. Na podstawie tych samych badań ustalana jest lista i udziały wydawnictw naukowych, których publikacje były kopiowane w danym roku podziałowym. Tu należy podkreślić, że udział twórczości naukowej i technicznej w całym wolumenie kopii reprograficznych stanowi stale ok. 92\%. Następnie na podstawie zbiorów Biblioteki Narodowej określa się nazwiska i imiona twórców utworów naukowych, które zostały opublikowane w danym roku podziałowym przez wydawnictwa ustalone w toku badań statystycznych. Po wykonaniu tych działań tworzone jest nowe lub uzupełniane jest „stare” konto autora, pokazane na rysunku 1. 


\begin{tabular}{|c|c|c|c|c|c|c|}
\hline Autor... & Wyszukaj & Generuj Raport & \multirow[t]{2}{*}{ Kolumny: } & Wszystkie & Jłacono $\square$ Pozc & tało do wypłaty \\
\hline & & & & & \multicolumn{2}{|c|}{ Pokaż/Ukryj szczegóły Z } \\
\hline \multicolumn{7}{|l|}{ Exportuj } \\
\hline \multicolumn{3}{|c|}{ Autor } & & Naliczono & Wypłacono & $\begin{array}{l}\text { Pozostało do } \\
\text { wyplaty }\end{array}$ \\
\hline Jan Kowalski* & & & & 405.61 & 0 & 405.61 \\
\hline \multirow[t]{2}{*}{$\mathbf{r}_{2010}$} & & & & 304.77 & 0 & 304.77 \\
\hline & Dom Organizatora & & & 304.77 & 0 & 304.77 \\
\hline \multirow[t]{2}{*}{$\boldsymbol{-}_{2007}$} & & & & 100.84 & 0 & 100.84 \\
\hline & PWN & & & 100.84 & 0 & 100.84 \\
\hline
\end{tabular}

* Zmiana imienia i nazwiska z uwagi na stanowisko, jakie zają Generalny Inspektor Ochrony Danych Osobowych (GIODO) w przedmiocie udostępniania przez Stowarzyszanie KOPIPOL danych osobowych autorów uprawnionych do otrzymania wypłat z repartycji indywidualnej.

Rysunek 1. Konto autorskie w systemie indywidualnych kont autorskich

Kolejnym i ostatnim etapem jest wypłata należnych wynagrodzeń uprawnionym autorom. Jak wielokrotnie podkreślano, wszystkie pieniądze zgromadzone przez KOPIPOL i przekazane do repartycji sa podzielone i przypisane do kont uprawnionych twórców.

W wyniku realizacji opisanej procedury podziałowej uzyskuje się imię i nazwisko twórcy oraz nazwy wydawnictw, numery ISBN lub ISSN, tytuły utworów, czyli pełne dane bibliograficzne, oraz należne twórcy kwoty. Dane te znakomicie identyfikują uprawnionego twórcę, ale nie pozwalają na dokonanie wypłaty. Zakres danych niezbędnych do dokonania wypłaty znaczaco rozszerzaja przepisy o podatku dochodowym od osób fizycznych. Oprócz imienia, nazwiska i adresu konieczna jest także znajomość numeru NIP uprawnionego oraz nazwy i adresu właściwego mu urzędu skarbowego. Z praktycznych powodów konieczne jest również pozyskanie adresu poczty elektronicznej i numeru konta bankowego.

Wszystkie te dane są w świetle przepisów prawa danymi osobowymi podlegającymi szczególnej ochronie. To ostatnie powoduje, że uzyskanie do nich legalnie dostępu w inny sposób niż bezpośrednio od uprawnionego jest niemożliwe. Najprostszym rozwiązaniem problemu docierania do uprawnionych byłoby coroczne ogłaszanie listy nazwisk, bez kwot i innych danych. Generalny Inspektor Ochrony Danych Osobowych (GIODO), na którego pomoc i zrozumienie dobra twórców liczył KOPIPOL, najpierw zwlekał z odpowiedzia, po czym udzielił jej w zdawkowej i enigmatycznej formie, bez żadnej wartości merytorycznej. Stracono ponad rok na zbędną korespondencję. 
Obrazuje to, jak trudne jest dokonanie wypłaty na rzecz uprawnionego twórcy, a zarazem, jaka przepaść dzieli podział pomiędzy twórców od podziału między wydawców. W tym ostatnim przypadku nie mamy bowiem żadnych ograniczeń co do możliwości dostępu do danych o uprawnionych, i to w dodatku danych pozwalających na wypłatę bez jakiegokolwiek współdziałania ze strony uprawnionego wydawcy. Dane o przedsiębiorcach są bowiem jawne i publicznie dostępne.

Dotychczas w KOPIPOL-u utworzono konta i przydzielono do wypłaty środki pieniężne dla ponad 35000 twórców. Do sfinalizowania repartycji indywidualnej konieczny jest osobisty kontakt uprawnionego ze Stowarzyszeniem.

Niedostateczna liczba tych kontaktów zmusza Stowarzyszenie do prowadzenia pracochłonnej i kosztownej akcji informacyjnej. Polega ona przede wszystkim na publikowaniu informacji o wypłatach z systemu repartycji indywidualnej w ogólnopolskich dziennikach, pismach branżowych, gazetach uczelnianych oraz elektronicznych biuletynach docierajacych systematycznie do grona potencjalnie uprawnionych autorów. Jednym z takich biuletynów stał się ostatnio „Biuletyn Ministerstwa Nauki i Szkolnictwa Wyższego”. Organizowane są również bezpośrednie spotkania przedstawicieli KOPIPOL-u z autorami, a Stowarzyszenie bierze czynny udział w konferencjach, seminariach i innych różnego rodzaju spotkaniach, podczas których o jego działaniach informowane jest środowisko akademickie, czyli główny beneficjent wynagrodzeń wypłacanych w ramach systemu repartycji indywidualnej.

Wszyscy zainteresowani zachęcani są do odwiedzania strony internetowej Stowarzyszenia: www.kopipol.pl, na której przygotowano wyszukiwarkę uprawnionych autorów (rys. 2). Po wpisaniu w nią imienia i nazwiska lub tytułu utworu, lub ISBN, lub ISSN każdy twórca może sprawdzić, czy należy mu się wynagrodzenie. Informację o wysokości należnego wynagrodzenia KOPIPOL może przekazać dopiero po przesłaniu deklaracji obejmujacej dane identyfikujące uprawnionego autora.

Wynikiem wyszukiwania (rys. 2) jest lista pozycji wydawniczych, za które autorowi należne jest wynagrodzenie z repartycji indywidualnej. Jeżeli twórca rozpoznaje utwory swojego autorstwa, pozostaje mu jedynie wypełnienie deklaracji i oświadczenia potwierdzającego autorstwo utworu lub utworów.

Wszystkie wyżej wymienione działania, choć kosztowne i pracochłonne, przynoszą efekty w postaci ciagłego wzrostu dynamiki wypłat w ramach repartycji indywidualnej. Na poniższych wykresach (wykresie 1 i 2) wyraźnie widać przyrosty o charakterze postępu geometrycznego wypłaconych kwot i liczby zrealizowanych wynagrodzeń. Szczególnie porównanie dwóch ostatnich kolumn wskazuje na nasilanie się pozytywnej tendencji.

Na koniec należy zwrócić uwagę na falę krytyki działań KOPIPOL-u i niektórych OZZ, jaką w ostatnich miesiącach 2014 r. można było obserwować na łamach ogólnopolskiej prasy. Jakie były jej przyczyny? Dlaczego koncentrowała się ona przede wszystkim na KOPIPOL-u, a jej źródłem była negatywna aktywność podmiotów zobowiąanych do wnoszenia opłat na podstawie art. 20 pr.aut.? 
Aby odpowiedzieć na te pytania, wystarczy wymienić dwa podstawowe „grzechy”, jakie KOPIPOL popełnia stale od pierwszych dni swojego istnienia.

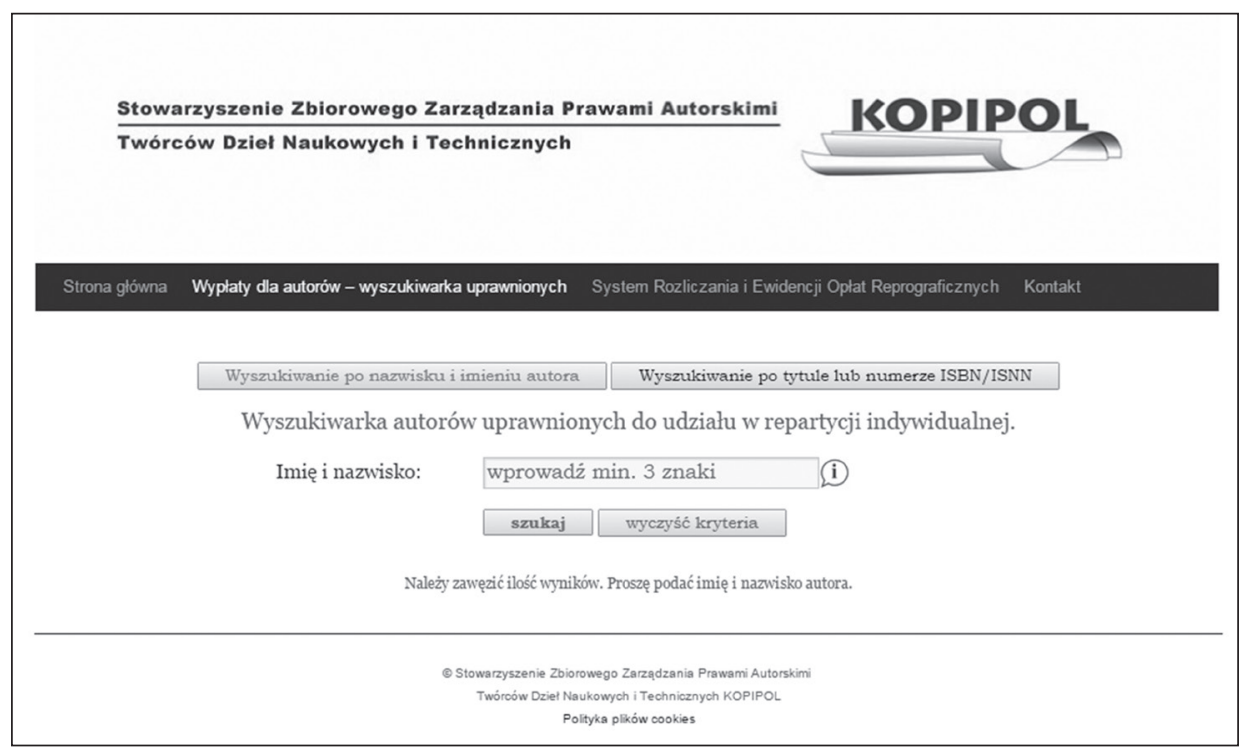

Rysunek 2. Okno wyszukiwarki uprawnionych autorów w systemie repartycji indywidualnej

Są to:

1) liczne, wygrane procesy sądowe przeciwko importerom urządzeń objętych opłatami, jak również wygrane procesy w kwestiach ważnych dla praktycznego funkcjonowania prawa autorskiego;

2) pionierski i oparty jedynie na wynikach pomiarów statystycznych system repartycji.

Na pierwszą kategorię „grzechów” składają się takie procesy, jak: znaczenie rodzaju nabywcy urządzenia reprograficznego a obowiązek opłaty - uchwała Sądu Najwyższego z 26 października 2011 r. (III CZP 61/11); okres przedawnienia roszczenia o zapłatę opłaty - wyrok Sądu Apelacyjnego w Poznaniu z 1 czerwca 2010 r. (I ACa 411/10); ocena charakteru prawnego opłaty oraz zgodności art. 105 ust. 2 w związku z art. 20 ust. 1 pkt 2 z Konstytucją - wyrok Trybunału Konstytucyjnego z 11 października 2011 r. (P 18/09); zakres przedmiotowy pojęcia urządzenie reprograficzne - wyrok Sądu Okręgowego w Warszawie z 17 lutego 2011 r. (XXIV C 370/08); interpretacja pojęcia „importer” - wyrok Sądu Najwyższego z 26 czerwca 2013 r. (V CSK 366/12).

Ostatni z wyżej wskazanych wyroków wydaje się najważniejszy. W procesie tym bowiem importerzy podjęli próbę całkowitego skasowania opłat od urządzeń kopiujących i czystych nośników. Rekompensaty dla twórców i wydawców sprowadzono by do zera. Oznaczałoby to faktyczne zlikwidowanie systemu opłat kompensujących kopiowanie utworów w ramach dozwolonego użytku. W opisanych procesach KOPIPOL działał w zupełnym osamotnieniu, choć każde z tych rozstrzygnięć miało fundamentalne znaczenie dla opłat należnych wszystkim organizacjom zbiorowego zarządzania. 


\section{Wykres 1}

Wypłaty z repartycji indywidualnej w latach 2010-2014 [narastająco w zł]

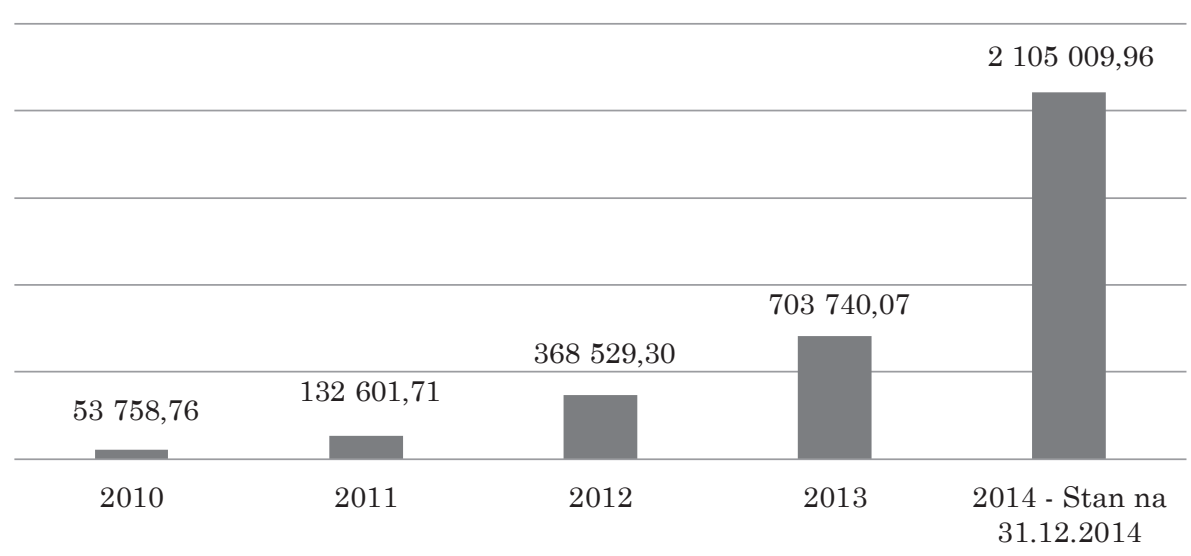

\section{Wykres 2}

Liczba wynagrodzeń wypłaconych w ramach systemu repartycji indywidualnej [narastajacco]

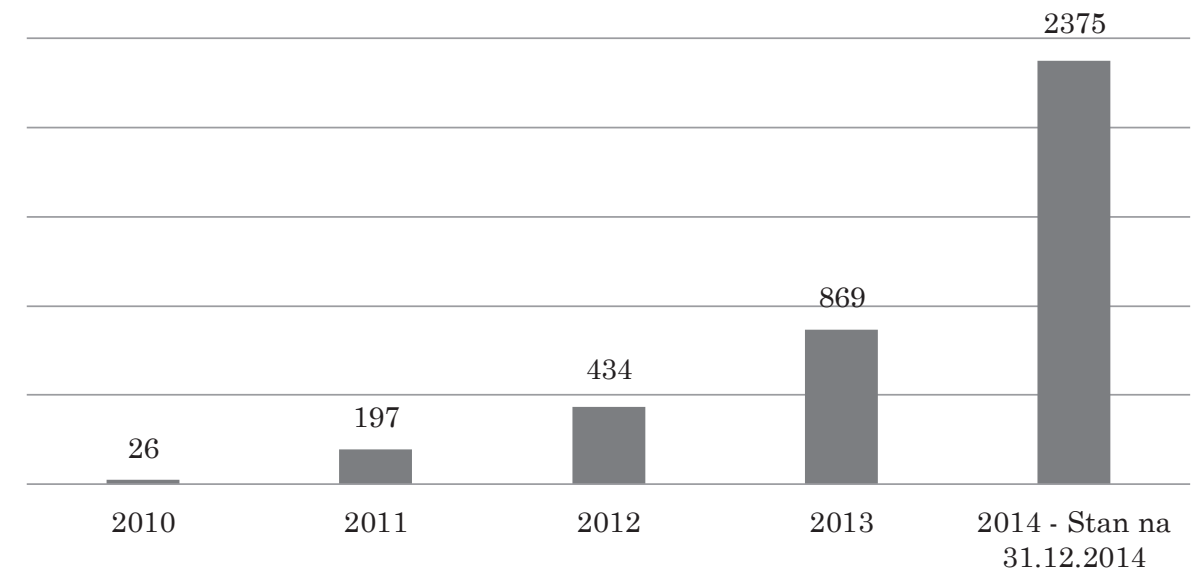

Oprócz wymienionych wcześniej postępowań sądowych wygraliśmy ponad sto procesów przeciwko importerom i właścicielom punktów ksero uchylającym się od opłaty. Były w tym również wygrane procesy karne przeciwko piratom reprograficznym, czyli tym punktom ksero, które w sposób nieuprawniony zwielokrotniały cudze utwory w celu ich rozpowszechniania.

Drugą kategorię „grzechów” stanowi nasz system repartycji. KOPIPOL jako jedyna organizacja zbiorowego zarządzania opiera podział inkasowanych kwot wyłącznie na wynikach pomiarów statystycznych. Tylko KOPIPOL regularnie na swoich stronach internetowych publikuje szczegółowe wyniki badań 
i ich metodologię oraz terminowo wypłaca kwoty należne innym organizacjom reprezentującym kategorie twórczości będące przedmiotem kopiowania reprograficznego. Nie stosujemy przy tym żadnych wag, parytetów ani innych rozwiązań o charakterze subiektywnym i arbitralnym, nieobjętych brzmieniem przepisów prawa autorskiego.

KOPIPOL stale domaga się, aby wszystkie zainkasowane przez OZZ kwoty były dzielone wyłącznie według wyników badań statystycznych, zarówno pomiędzy uprawnione stowarzyszenia, jak i w ramach repartycji indywidualnej. Procedury tych badań winny być jawne, a badania systematycznie powtarzane.

Drugi podstawowy postulat to ścisłe stosowanie się do zapisów ustawy pr.aut. tak, aby woluntarystyczne rozdawnictwo nie było mylone ze zgodna z prawem repartycją pomiędzy stowarzyszenia oraz repartycją indywidualną.

Najważniejszym zadaniem na przyszłość wydaje się obecnie postulat KOPIPOL-u, od pewnego czasu popierany także przez inne OZZ (takie jak ZAiKS, SAWP i ZPAV), usunięcia niezgodności pomiędzy rozporządzeniem Ministra Kulturyi Dziedzictwa Narodowego wydanym na podstawie art. 20 ust. 5 pr.aut.a ust. 1 tego artykułu oraz z zakresem delegacji do wydania tego rozporządzenia. Nie powinno budzić wątpliwości, że o przedmiotowym zakresie opłat, tzn. o tym, które urządzenia są objęte opłatami, rozstrzyga w sposób kategoryczny art. 20 ust. 1 pr.aut. Przedmiotem rozporządzenia wykonawczego wydawanego na podstawie art. 20 ust. 5 pr.aut. może i powinno być jedynie określenie wysokości opłat odnoszących się do poszczególnych rodzajów urządzeń umożliwiających kopiowanie egzemplarzy utworów w ramach własnego użytku osobistego na terytorium Rzeczypospolitej, bez względu na to, czy jest to jedyna funkcja danego urządzenia lub nośnika, kto jest właścicielem urządzenia lub jego posiadaczem, kto je wyprodukował lub skąd (z którego państwa) zostało i przez kogo sprowadzone (importowane), czy jest nowe, czy używane. To samo dotyczy odpowiednio związanych z tymi urządzeniami czystych nośników.

Ponieważ, wraz z postępem techniki, na rynku stale pojawiają się nowe generacje urządzeń umożliwiających kopiowanie w ramach własnego użytku osobistego i czystych nośników, a dotychczasowe odgrywają znaczenie marginalne lub nie sa wykorzystywane do tego celu, opłaty od nowych rodzajów urządzeń powinny być określane odpowiednio do opłat za te urządzenia i nośniki, które sa podobne w swojej funkcji kopiowania egzemplarzy utworów w ramach własnego użytku osobistego, a rozporządzenie wykonawcze wydane na podstawie art. 20 ust. 5 pr.aut. powinno obligować Ministra Kultury i Dziedzictwa Narodowego do corocznego aktualizowania wysokości opłat za poszczególne rodzaje urządzeń i nośników.

Jacek Kargul

Stowarzyszenie KOPIPOL

jacek@kopipol.pl

prof. dr hab. inż. Mieczystaw E. Poniewski Przewodniczacy Stowarzyszenia KOPIPOL meponiewski@pw.plock.pl 


\section{REPARTITION IN THE FIELD OF REPROGRAPHICS \\ - EXPERIENCES OF KOPIPOL ASSOCIATION}

\section{Summary}

In response to the phenomenon of a dynamic development of a reprographic technique of copying works, the Act on Copyright and Related Rights of 1994 introduced relevant fees to the Polish legal order. Their aim was to compensate the losses incurred as a result of copying copyrighted works using this technique. The collection of reprographic fees, of which half of the collected sum is due to authors, has been entrusted to the Association of Copyright Collective Administration for Authors of Scientific and Technical Works KOPIPOL, created in 1995. The duties of KOPIPOL include not only the collection of those fees, but also their allocation and distribution among authors of scientific and technical works.

The collection turned out to be complicated, expensive and time-consuming, mainly because of constant attempts to avoiding paying the fees. As a result, KOPIPOL is forced to seek enforcement of due payments by way of numerous judicial proceedings. Funds collected in fees are first of all allocated to collective management organisations representing different categories of creativity, which according to statistical surveys undergo reprographic copying, and next to the authors of scientific and technical works. As part of the latter, called Individual Repartition, sums are paid out to authors identified by names and surnames.

The effectiveness of these activities is systematically increasing. So far KOPIPOL has paid remunerations to 2375 authors, for a total exceeding 2 million zlotys. 